\title{
NILAI-NILAI PENDIDIKAN KARAKTER DI PONDOK PESANTREN BAHRUL ULUM TAMBAKBERAS JOMBANG
}

\author{
Oleh: Dr. Ali Muttaqin, M.Pd.I *
}

\begin{abstract}
Character education is essentially a virtue value education that aims to shape the character of students so that they are dignified and noble. Islamic boarding schools are a national education subsystem that has been developing for along time and has proven successful in educating santri to have noble character. The success of Islamic boarding schol in educating their santri characters because Islamic boarding schools have a number of character values instilled in their students by using strategies and methods comprehensively. This study examines the value of character education in Bahrul Ulum Islamic boarding school in Tambakberas Jombang. This study uses a qualitative approach that aims to describe the subject of research phenomenologically. The results of this study are that the values of character education instilled in Bahrul Ulum Islamic boarding school are 10 items, namely: faithful, honesty, sincerity, obedience and respect, simplicity, brotherhood independence, love in science, freedom and leadership. These character of values are a yardstick for the goodness of someone who must be manifested in the mind, attitude and behavior in relation to God, itself, family, society, nation people, and natural environment.
\end{abstract}

\begin{abstract}
Abstrak
Pendidikan karakter pada hakikatnya adalah pendidikan nilai-nilai kebajikan yang bertujuan untuk membentuk karakter peserta didik agar bermartabat dan berakhlak mulia. Pondok pesantren merupakan sub sistem pendidikan nasional yang berkembang sejak lama dan terbukti berhasil mendidik santri memiliki karakter yang mulia. Keberhasilan pesantren dalam mendidik karakter santrinya, karena pesantren memiliki sejumlah nilai-nilai karakter yang ditanamkan kepada peserta didiknya dengan menggunakan strategi dan metode secara komprehensip. Penelitian ini mengkaji nilai-nilai pendidikan karakter di Pondok Pesantren Bahrul Ulum Tambakberas Jombang. Penelitian ini menggunakan pendekatan kualitatif yang bertujuan mendeskripsikan subjek penelitian secara fenomenologis. Hasil penelitian ini adalah bahwa nilai-nilai pendidikan karakter yang ditanamkan di PP Bahrul Ulum terdapat sepuluh butir, yaitu: keimanan, kejujuran, keikhlasan, ketaatan dan penghormatan, kesederhanaan, kemandirian, persaudaraan, cinta ilmu pengetahuan, kebebasan dan kepemimpinan. Nilai-nilai karakter tersebut merupakan tolok ukur kebaikan seseorang yang harus diwujudkan dalam pikiran, sikap dan perilaku dalam hubungannya dengan Tuhan, diri sendiri, keluarga, masyarakat, bangsa dan lingkungan alam.
\end{abstract}

\footnotetext{
*Dr. Ali Muttaqin, M.Pd.I Dosen UIN Sunan Ampel Surabaya DPK Pada Universitas KH. A. Wahab Hasbullah Jombang.
} 


\section{Ali Muttaqin}

\section{A. Latar Belakang}

Pendidikan karakter saat ini sedang gencar dilaksanakan, khususnya pada jalur pendidikan formal. Hal ini berlangsung setelah Kementerian Pendidikan dan Kebudayaan mencanangkan gerakan nasional pendidikan karakter tanggal 20 Mei 2010. ${ }^{1}$ Pendidikan karekter sebagai upaya untuk mengatasi krisis moral dan akhlak masyarakat yang dalam dekade terakhir ini cenderung semakin merosot.

Berbagai krisis moral dan akhlak seperti tawuran antar pelajar, penyalahgunaan narkoba, pergaulan bebas oleh para pelajar dan generasi muda, menurunnya budaya hormat dan sopan santun, korupsi, terorisme dan separatisme menjadi latar belakang perlunya pendidikan karakter dilaksanakan. Muzhoffar Ikhwan, menyatakan bahwa pendidikan karakter (character education) dalam konteks sekarang sangat relevan untuk mengatasi krisis moral yang sedang melanda bangsa kita. ${ }^{2}$

Relevan dengan fenomena krisis moral dan akhlak masyarakat di atas, patut untuk direnungkan pernyataan Thomas Lickona, seorang penggagas pendidikan karakter di Amerika Serikat, tentang sepuluh tanda-tanda zaman yang menggambarkan kemerosotan nilai-nilai moral suatu bangsa, yakni: meningkatnya kekerasan di kalangan remaja, (2) penggunaan bahasa dan kata-kata yang memburuk, (3) pengaruh peer-group yang kuat dalam tindak kekerasan, (4) meningkatnya perilaku merusak diri, seperti penggunaan narkoba, alkohol dan seks

\footnotetext{
${ }^{1}$ Gerakan Nasional Pendidikan Karakter dicanangkan secara resmi oleh Menteri Pendidikan Nasional M. Nuh di Jakarta pada Acara Peringatan Hari Pendidikan Nasional, 20 Mei 2010, http:/www.hidayatullah.com /15/07/2011, akses tanggal 25 Oktober 2018.

${ }^{2}$ Muzhoffar Ikhwan, Pendidikan Karakter: Konsep dan Implementasinya Dalam Pembelajaran di Sekolah/Madrasah, Makalah dipresentasikan dalam diskusi dosen Fakultas Agama Islam UII, tanggal 2 Nopember 2011.
} 


\section{Nilai-Nilai Pendidikan Karakter Di Pondok Pesantren \\ Bahrul Ulum Tambakberas Jombang}

bebas, (5) semakin kaburnya pedoman moral baik dan buruk, (6) menurunnya daya juang dan etos kerja, (7) semakin rendahnya rasa hormat kepada orang tua dan guru, (8) rendahnya rasa tanggung jawab pribadi dan sosial, (9) membudayanya ketidakjujuran, dan (10) adanya rasa saling curiga dan kebencian di antara sesama. Menurut Lickona, apabila tanda-tanda zaman tersebut telah ada pada suatu bangsa maka kehancuranlah yang akan menimpa bangsa tersebut. ${ }^{3}$ Jika dicermati, kesepuluh tanda-tanda kemerosotan nilai-nilai moral bangsa tersebut telah terjadi di Indonesia saat ini, bahkan dalam dekade terakhir ini cenderung meningkat.

Pendidikan karakter dimaksudkan untuk menanamkan kembali nilai-nilai dasar kebangsaan yang telah lama menjadi spirit dan falsafah kehidupan bermasyarakat dan berbangsa. Karakter merupakan nilai-nilai perilaku manusia yang berhubungan dengan Tuhan Yang Maha Esa, diri sendiri, sesama manusia, lingkungan, dan kebangsaan yang terwujud dalam pikiran, sikap, perasaan, perkataan, dan perbuatan berdasarkan norma-norma agama, hukum, tata krama, budaya, dan adat istiadat. Karakter adalah perilaku yang tampak dalam kehidupan sehari-hari dalam bersikap atau bertindak. ${ }^{4}$

Menurut Thomas Lickona, bahwa karakter yang baik sebagai kehidupan dengan melakukan tindakan-tindakan yang benar sehubungan dengan diri sendiri

${ }^{3}$ Thomas Lickona, Educating for Character: How Our Schools Can Teach Respect and Responsibility (New York: Bantam Books, 1991), hlm. 13-20.

${ }^{4}$ Muchlas Samani dan Harianto, Konsep dan Model Pendidikan Karakter (Bandung: Remaja Rosdakarya, 2011), hlm. 41. 


\section{Ali Muttaqin}

dan orang lain. ${ }^{5}$ Nilai-nilai yang perlu ditanamkan kepada peserta didik antara lain: religius, jujur, toleransi, disiplin, kerja keras, kreatif, mandiri, demokratis, rasa ingin tahu, semangat kebangsaan, cinta tanah air, bersahabat dan komunikatif, cinta damai, peduli lingkungan, peduli sosial, dan tanggung jawab. ${ }^{6}$

Pendidikan karakter bertujuan membentuk tabiat, sikap dan kepribadian seseorang dengan cara menanamkan nilai-nilai moral, sehingga nilai-nilai tersebut mendarah daging, menyatu dalam hati, pikiran, ucapan dan perbuatan. ${ }^{7}$ Pendidikan Karakter juga bertujuan membentuk bangsa yang tangguh, kompetitif, berakhlak mulia, bermoral, bertoleran, bergotong-royong, berjiwa patriotik, berkembang dinamis, berorientasi ilmu pengetahuan dan teknologi, yang semuanya dijiwai oleh iman dan takwa kepada Tuhan Yang Maha Esa berdasarkan Pancasila.8

Dalam implementasinya, Kementerian Pendidikan dan Kebudayaan menjadikan pola pendidikan pesantren sebagai salah satu model pendidikan karakter untuk diterapkan pada lembaga-lemebaga pendidikan formal. Hasil Seminar Nasional Pendidikan Karakter Bangsa Melalui Pola Pendidikan Pesantren Kemendiknas tahun 2011, merekomendasikan perlunya pendidikan karakter yang Islami melalui pola pendidikan pesantren, baik di sekolah, keluarga maupun di masyarakat. ${ }^{9}$ Pada

\footnotetext{
${ }^{5}$ Thomas Lickona, Educating for Character: How Our Schools Can Teach Respect and Responsibility (New York: Bantam Books, 1991), hlm. 81.

${ }^{6}$ Kementerian Pendidikan Nasional, Naskah Akademik Pengembangan Pendidikan Budaya dan Karakter Bangsa, Tahun 2010, hlm. 10-11.

${ }^{7}$ Abuddin Nata, Akhlak Tasawuf dan Karakter Mulia (Jakarta: Radjagrafindo Persada, 2013), hlm. 288.

${ }^{8}$ http://nasional.kompas.com/20 Mei 2011. diakses tanggal 28 Oktober 2018.

${ }^{9}$ Panitia, Ringkasan Eksekutif Seminar Nasional Pendidikan (Jakarta: Badan Penelitian dan Pengembangan Kementerian Pendidikan Nasional, Jakarta, 2010), hlm. 39-40.
} 


\section{Nilai-Nilai Pendidikan Karakter Di Pondok Pesantren \\ Bahrul Ulum Tambakberas Jombang}

tataran inilah penelitian tentang pelaksanaan pendidikan karakter di pesantren menjadi sangat urgen.

Menjadikan pendidikan pesantren sebagai model pendidikan karakter tepat sekali, karena pesantren merupakan salah satu sub sistem pendidikan nasional yang berkembang sejak lama dan telah terbukti berhasil mendidik santri/siswa dalam berbagai aspek, meliputi intelektual, emosional dan watak religius. Nilai-nilai yang tengah digali dan ditanamkan kembali oleh Kementerian Pendidikan dan Kebudayaan melalui pendidikan karakter, seperti jujur, ikhlas, tanggung jawab, mandiri, sopan santun, solidaritas, sikap hormat dan sebagainya, secara praktis jauh sebelumnya telah dikembangkan dalam pendidikan pesantren. ${ }^{10}$

Keberhasilan pesantren dalam membentuk karakter santri/siswa karena dalam pesantren siswa diasramakan dalam bimbingan dan pengawasan kiai, adanya wibawa dan keteladanan kiai, dan suasana pesantren yang religius. Karena itu, pendidikan karakter di pesantren dilaksakanan dengan pendekatan yang komprehensif, meliputi pengajaran nilai-nilai, pembiasaan, keteladanan, kedisiplinan, dan penciptaan lingkungan yang religius, kesemuanya merupakan kultur pesantren yang mampu membentuk santri yang berkarakter baik.

Di antara sekian banyak pesantren yang telah melaksanakan pendidikan karakter adalah Pondok Pesantren Bahrul Ulum Tambakberas Jombang (PP Bahrul Ulum). Pesantren ini merupakan model pesantren yang memadukan sistem salaf dan

\footnotetext{
${ }^{10}$ Pupuh Fathurrohman dkk., Pengembangan Pendidikan Karakter (Bandung: PT Refika Aditama, 2013), hlm. 127-133.
} 


\section{Ali Muttaqin}

khalaf, yang bertujuan membentuk manusia beriman, bertakwa, beramal salih, cerdas, terampil, mandiri, bertanggungjawab, berilmu pengetahuan, berbuat keselarasan dan keharmonisan antara jasmani dan rohani. ${ }^{11}$ Dari tujuan tersebut diharapkan lahir dari pesantren manusia-manusia yang memiliki kepribadian yang tangguh, jujur, amanah, berkualitas, mandiri dan berakhlak karimah, memiliki jiwa pemimpin, mencintai ilmu dan memiliki bekal ilmu pengetahuan dan teknologi.

Untuk membentuk manusia-manusia yang berkarakter mulia tersebut, PP Bahrul Ulum telah mengembangkan sejumlah nilai karakter yang digali dari berbagai sumber. Nilai-nilai karakter itu ditanamkan/dididikkan kepada para santri/siswanya melalui berbagai strategi, seperti pembelajaran, pembiasaan, keteladanan dan tradisi-tradisi yang berlangsung sejak lama di pesantren.12 Penelitian ini bermaksud mengkaji tentang nilai-nilai pendidikan karakter di PP Bahrul Ulum Tamabkberas Jombang.

\section{B. Permasalahan, Tujuan dan Manfaat Penelitian}

Bertolak dari latar belakang di atas, maka permasalahan yang dipecahkan dalam penelitian ini adalah nilai-nilai karakter apa saja yang ditanamkan kepada santri di PP Bahrul Ulum? Tujuan penelitian ini adalah mendeskripsikan nilai-nilai karakter yang dikembangkan dan ditanamkan di PP Bahrul Ulum. Sedangkan hasil penelitian ini memberikan kontribusi pemikiran tentang paradigma, konsep, strategi

\footnotetext{
${ }^{11}$ Sumber: Profil Pondok Pesantren Bahrul Ulum Tambakberas Jombang.

${ }^{12}$ Hasil penelitian pendahuluan pada Pondok Pesantren Bahrul Ulum Tambakberas Jombang, tanggal 4 Nopember 2018.
} 


\section{Nilai-Nilai Pendidikan Karakter Di Pondok Pesantren \\ Bahrul Ulum Tambakberas Jombang}

dan metode pendidikan karakter yang islami, untuk perbaikan pendidikan karakter pada lembaga-lembaga pendidikan formal seperti sekolah dan madrasah.

\section{Metode Penelitian}

Penelitian ini merupakan jenis penelitian lapangan dengan pendekatan kualitatif bermaksud mendeskripsikan subjek penelitian secara fenomenologis, kemudian menginterpretasikan data yang diperoleh agar menghasilkan temuan yang mendasar berupa teori atau menguatkan teori yang telah ada. Sumber data penelitian adalah para kiai pengasuh, ustaz/pengurus dan santri PP Bahrul Ulum. Teknik pengumpulan data menggunakan observasi partisipatif, interview, dokumentasi dan angket. Analisis data menggunakan model analisis kualitatif dari Miles dan Huberman, yaitu analisis data meliputi tiga tahap, yaitu: reduksi data, penyajian data, dan penarikan kesimpulan dan verifikasi. ${ }^{13}$

\section{D.Kajian Teori}

\section{Pengertian Pendidikan Karakter}

Secara etimologis kata karakter (Inggris: character) berasal dari bahasa Yunani (Greek), yaitu charassein yang berarti mengukir, melukis, memahatkan, atau menggoreskan. ${ }^{14}$ Menurut Rutland, "character" yang berarti "dipahat", artinya sebuah kehidupan seperti sebuah blok granit yang dengan hati-hati dipahat yang pada

\footnotetext{
${ }^{13}$ Sugiyono, Metode Penelitian Pendidikan: Pendekatan Kuantitatif, Kualitatif, dan $R$ \& D (Bandung: Alfabeta, 2008), hlm. 247.

${ }^{14}$ John M. Echols dan Hassan Shadily, Kamus Inggris Indonesia (Jakarta: Gramedia, 1979), hlm. 107. 


\section{Ali Muttaqin}

akhirnya akan menjadi sebuah mahakarya. ${ }^{15}$ Dalam bahasa Arab, karakter diartikan "khuluq, sajiyyah, tab'u" (budi pekerti, tabi'at dan watak). Terkadang juga diartikan "syakhsiyyah" yang artinya kepribadian (personality). ${ }^{16}$ Dalam Kamus Lengkap Bahasa Indonesia, kata "karakter" diartikan sifat-sifat kejiwaan, akhlak, tabiat, watak atau budi pekerti yang membedakan seseorang dari yang lain. ${ }^{17}$

Secara terminologi, istilah karakter diartikan sebagai sifat manusia pada umumnya di mana manusia mempunyai banyak sifat yang tergantung dari faktor kehidupannya sendiri. ${ }^{18}$ Karakter mengacu kepada serangkaian sikap (attitudes), perilaku (behaviors), motivasi (motivations), dan keterampilan (skills). ${ }^{19}$ Dalam kamus psikologi, arti karakter adalah kepribadian ditinjau titik tolak etis atau moral, misalnya kejujuran seseorang. ${ }^{20}$

Menurut Darmiyati Zuchdi, karakter dimaknai sebagai seperangkat sifat-sifat yang selalu dikagumi sebagai tanda-tanda kebaikan, kebajikan dan kematangan moral seseorang. ${ }^{21}$ Abdullah Munir mendefinisikan karakter sebagai sebuah pola, baik itu pikiran, sikap, maupun tindakan yang melekat pada diri seseorang dengan

\footnotetext{
${ }^{15}$ Mark Rutland, Karakter Itu Penting, terj. Ly Yen (Jakarta: Light Publishing, 2009), hlm.1.

${ }^{16}$ Aisah Boang dalam Supiana, Mozaik Pemikiran Islam: Bunga Serampai Pemikiran Pendidikan Indonesia (Jakarta: Ditjen Dikti, 2011), hlm. 3.

${ }^{17}$ Kamisa, Kamus Lengkap Bahasa Indonesia (Surabaya: Kartika, 1997), hlm. 281. Juga: Melly Latifah "Peranan Keluarga Dalam Pendidikan Karakter Anak" dalam www.Strawberrysekolahbakatprestasi.wordpress.com, 17 Oktober 2010, diakses tanggal 10 Oktober 2018

${ }^{18}$ Departemen Pendidikan Nasional, Kamus Besar Bahasa Indonesia ... , hlm. 219.

${ }^{19} \mathrm{http}$ ///akhmadsudrajat.wordpress.com/2010/09/15/konsep-pendidikan-karakter, diakses tanggal 29 Oktober 2018

${ }^{20}$ Agus Zainul Fitri, Reinventing Human Character: Pendidikan Karakter Berbasis Nilai \& Etika di Sekolah (Yogyakarta: Ar-Ruzz Media, 2012), hlm. 20.

${ }^{21}$ Darmiyati Zuchdi, Humanisasi Pendidikan (Jakarta: Bumi Aksara, 2008), hlm. 39.
} 


\section{Nilai-Nilai Pendidikan Karakter Di Pondok Pesantren \\ Bahrul Ulum Tambakberas Jombang}

sangat kuat dan sulit dihilangkan.22 Karakter merupakan nilai-nilai perilaku manusia yang berhubungan dengan Tuhan Yang Maha Esa, diri sendiri, semua manusia, lingkungan dan kebangsaan yang terwujud dalam pikiran, perasaan, perkataan dan perbuatan berdasarkan norma-norma agama, hukum, tata krama, budaya dan adat istiadat. ${ }^{23}$

Dari beberapa pengertian karakter menurut para ahli di atas, dapat dinyatakan bahwa karakter adalah watak, tabi'at, kualitas mental, moral, akhlak atau budi pekerti seseorang, yang merupakan kepribadian yang khas, menjadi pendorong dan penggerak seseorang untuk bertindak, serta yang membedakannya dengan individu lain. Seseorang dapat dikatakan berkarakter baik apabila telah berhasil menyerap nilai-nilai dan keyakinan yang dikehendaki kelompok, masyarakat, bangsa dan negara di mana dia hidup di dalamnya serta digunakan sebagai kekuatan moral dalam hidupnya.

Dalam perspektif pendidikan Islam, karakter disebut dengan akhlak. Ibnu Miskawaih seorang penggagas pendidikan etika mengartikan akhlak:

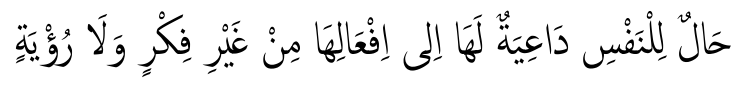

Artinya: Kepribadian yang tertanam dalam jiwa yang mendorongnya untuk melakukan perbuatan tanpa memerlukan pemikiran dan pertimbangan. ${ }^{24}$

${ }^{22}$ Abdullah Munir, Pendidikan Karakter (Yogyakarta: Pedagogia, 2010), hlm. 3.

${ }^{23}$ Azimabadi Badr, Etiquettes of Islamic Life (Kuala Lumpur: Adam Publisher Distributors, 2000), hlm. 4.

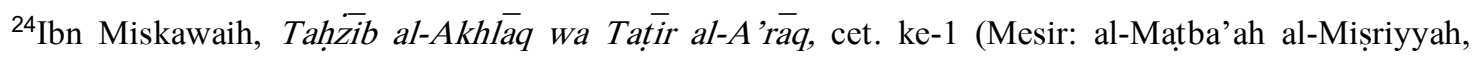
1934), hlm. 40. 


\section{Ali Muttaqin}

Menurut Miskawaih, karakter (khuluq) merupakan suatu keadaan jiwa. Keadaan ini menyebabkan jiwa bertindak tanpa berpikir atau mempertimbangkan secara mendalam. Keadaan ini ada dua jenis; Pertama, alamiah dan bertolak dari watak, misalnya pada orang yang gampang sekali marah karena hal yang paling kecil, atau takut menghadapi insiden yang paling sepele. Kedua, tercipta melalui kebiasaan dan latihan, pada mulanya keadaan ini terjadi karena dipertimbangkan dan dipikirkan, namun karena praktik terus menerus sehingga menjadi karakter. Karena itu menurut Miskawaih, karakter bersifat alami dan dapat berubah cepat atau lambat melalui disiplin serta nasihat-nasihat yang mulia. ${ }^{25}$

Sementara itu, Imam al-Ghazali mengatakan akhlak adalah:

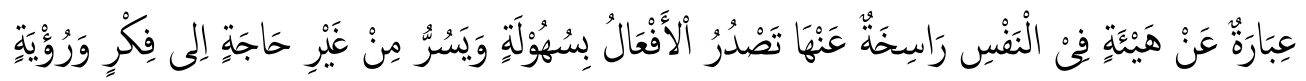
Artinya: Kondisi yang tertanam kuat dalam jiwa yang menimbulkan macam-macam perbuatan dengan gampang, tanpa memerlukan pemikiran dan pertimbangan. ${ }^{26}$

Nilai adalah sesuatu yang dianggap bermakna bagi kehidupan seseorang yang dipertimbangkan berdasarkan kualitas benar-salah, baik-buruk, indah-tidak indah, yang orientasinya bersifat antroposentris (kemanusiaan) dan theosentris (ketuhanan).27 Maka, pendidikan karakter adalah upaya guru/pendidik untuk menanamkan nilai-nilai kepada siswa/peserta didik.

\footnotetext{
${ }^{25}$ Ibid., hlm. 56.

${ }^{26}$ Imam al-Gazali, Ihyā' Ulüm al-Din (Bairut: Dār al-Fikr, t.t.), III: 56.

${ }^{27}$ Rohmat Mulyana, Mengartikulasikan Pendidikan Nilai (Bandung: Alfabeta, 2004), hlm. 117-118.
} 


\section{Nilai-Nilai Pendidikan Karakter Di Pondok Pesantren \\ Bahrul Ulum Tambakberas Jombang}

\section{Nilai-Nilai Pendidikan Karakter}

Pendidikan karakter pada hakikatnya adalah pendidikan nilai-nilai kebajikan yang bertujuan untuk membentuk karakter peserta didik agar bermartabat dan berbudaya luhur. ${ }^{28}$ Mardiatmadja menyatakan bahwa pendidikan nilai merupakan bantuan kepada peserta didik agar menyadari dan mengalami nilai-nilai serta menempatkan secara integral dalam keseluruhan hidupnya. ${ }^{29}$

Ratna Megawangi, seorang penggiat pendidikan karakter di Indonesia telah menyusun butir-butir karakter mulia yang selayaknya diajarkan kepada anak, yang kemudian disebut sebagai 9 (sembilan) pilar pendidikan karakter yaitu: (1) cinta Tuhan, (2) tanggung jawab, kedisiplinan dan kemandirian, (3) amanah atau jujur, (4) hormat dan santun, (5) kasih sayang, kepedulian dan kerjasama, (6) percaya diri, kerja keras, kreatif dan pantang menyerah, (7) keadilan dan kepemimpinan, (8) baik dan rendah hati, dan (9) toleransi, cinta damai dan persatuan. ${ }^{30}$

Sedangkan Ary Gunanjar Agustian mengidentifikasikan tujuh karakter utama yang dimuat dalam bukunya "Bangkit dengan Tujuh Budi Utama", yaitu: (1) jujur, (2) tanggung jawab, (3) visioner, (4) disiplin, (5) kerja sama, (6) adil, dan (7) peduli. ${ }^{31}$

Sementara itu, Character Count di Amerika Serikat mengidentifikasikan sejumlah karakter mulia yang menjadi pilar pendidikan karakter adalah: (1)

\footnotetext{
${ }^{28}$ Maksudin, Pendidikan Nilai Komprehensif Teori dan Praktik (Yogyakarta: UNY Press, 2009), hlm. 18.

${ }^{29}$ Mardiatmadja dalam Rohmat Mulyana, Mengartikulasikan Pendidikan Nilai (Bandung: Alfabeta, 2004), hlm. 119.

${ }^{30}$ Ratna Megawangi, Membiarkan Berbeda Sudut Pandang Baru Tentang Relasi Gender (Bandung: Mizan, 1999), hlm. 43. v-xi.

${ }^{31}$ Ary Gunanjar Agustian, Bangkit Dengan Tujuh Budi Utama (Jakarta: PT Arga Publishing, 2009), hlm.
} 


\section{Ali Muttaqin}

trustworthiness (dapat dipercaya), (2) respect (rasa hormat dan perhatian), (3) responsibility (tanggung jawab), (4) fairness (jujur), (5) caring (peduli), (6) citizenship (kewarganegaraan), (7) honesty (ketulusan), (8) courage (berani), (9) diligence (tekun), dan (10) integrity (integritas). ${ }^{32}$

\section{Strategi Pendidikan Karakter}

Thomas Lickona, seorang penggagas pendidikan karakter dari State University of New York, Cortland, dari serangkaian penelitiannya tentang pendidikan nilai pada sekolah-sekolah di Amerika dan Kanada tahun 1985, Lickona telah membangun suatu kerangka teori tentang pendidikan nilai untuk membentuk karakter anak. Dalam buku hasil penelitianya "Educating for Character" Ia menyatakan bahwa karakter yang baik itu terdiri dari tiga komponen yang saling berhubungan, yaitu: moral knowing (pengetahuan moral/mengetahui hal yang baik), moral feeling (perasaan moral/ menginginkan hal yang baik), dan moral acting (perilaku moral/melakukan hal yang baik). ${ }^{33}$

Ketiga komponen karakter ini menunjuk pada tahapan pemahaman sampai pelaksanaan nilai dalam kehidupan sehari-hari. Ketiganya tidak serta merta terjadi dalam diri seseorang, tetapi bersifat prosesual, artinya tahapan ketiga hanya mungkin terjadi setelah tercapai tahapan kedua, dan tahapan kedua hanya terjadi setelah tercapai tahapan pertama. ${ }^{34}$

\footnotetext{
${ }^{32}$ E. Mulyasa, Manajemen Pendidikan Karakter (Jakarta: Bumi Aksara, 2011), hlm. 16.

${ }^{33}$ Thomas Lickona, Educating for Character..., hlm. 81.

${ }^{34}$ Ibid.
} 


\section{Nilai-Nilai Pendidikan Karakter Di Pondok Pesantren}

Bahrul Ulum Tambakberas Jombang

Menurut Lickona, pendidikan nilai untuk menghasilkan karakter yang meliputi tiga komponen itu, perlu menggunakan pendekatan yang komprehensif dan strategistrategi berbasis sekolah luas. Pendekatan ini meliputi tiga ranah, yaitu: pertama, strategi-strategi kelas untuk mengajarkan nilai-nilai yang baik melalui kurikulum sekolah dan menggunakan pelajaran akademik sebagai kendaraan untuk membahas permasalahan etika; kedua, menciptakan budaya moral yang positif melalui disiplin sekolah dalam memberikan teladan, mengembangkan dan menegakkan nilai-nilai sekolah dalam keseluruhan lingkungan sekolah; dan ketiga, kerja sama sekolah, orang tua, dan masyarakat untuk memenuhi kebutuhan anak-anak dan membantu perkembangan mereka. ${ }^{35}$

Aplikasi kerangka teoritik tersebut dalam konteks penelitian pendidikan karakter di pesantren, bahwa pesantren memiliki sejumlah nilai-nilai luhur yang mendasari pendidikannya, yang bersumber pada ajaran Islam dan budaya masyarakat. Pendekatan komprehensif dalam pendidikan nilai menurut Lickona itu, telah sejak lama dilaksanakan di pesantren melaui strategi pembelajaran, pembudayaan tradisi-tradisi pesantren dan penciptaan lingkungan yang kondusif.

\section{E. Hasil Penelitian}

\section{Nilai-Nilai Pendidikan Karakter di PP Bahrul Ulum}

PP Bahrul Ulum bertujuan mencetak anak didik menjadi manusia beriman, bertakwa, beramal salih, berakhlak karimah, memiliki ilmu pengetahuan, cerdas,

${ }^{35}$ Ibid., hlm. 106-107. 


\section{Ali Muttaqin}

terampil, bertanggung jawab, memiliki dedikasi yang tinggi untuk menegakkan kebenaran. Dari tujuan itu diharapkan lahir manusia berkepribadian yang tangguh, ulet dan amanah, berkualitas, mandiri, berakhlak karimah, berjiwa pemimpin dan memiliki bekal ilmu pengetahuan dan teknologi. ${ }^{36}$

Untuk mewujudkan tujuannya, PP Bahrul Ulum memiliki nilai-nilai karakter yang ditanamkan kepada santrinya. Dari kegiatan penelitian diketahui setidaknya terdapat sepuluh butir-butir nilai karakter yang membentuk karakter mereka, yaitu:

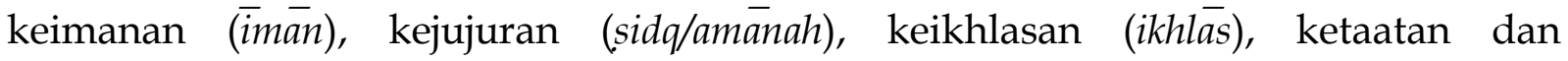

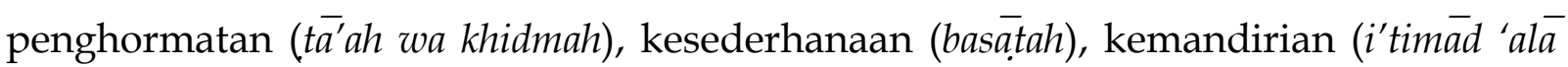
al-nafs), persaudaraan (ukhuwah), kebebasan (hurriyyah), cinta ilmu pengetahuan, dan nilai kepemimpinan (imāmah). Para pendiri dan pengasuh terdahulu telah mewariskan nilai-nilai tersebut secara turun-temurun, dari generasi ke generasi pengasuh hingga sekarang. ${ }^{37}$

Sistem nilai kepesantrenan senantiasa diejawantahkan kepada seluruh warga pesantren. Kiai pengasuh pesantren berharap santri dan guru menjiwai nilai-nilai kepesantrenan dan menjadikannya sebagai kekuatan moral spiritual yang melandasi semua aktivitas di pesantren, agar apa yang telah diwariskan oleh para kiai pengasuh yang telah nyata keberhasilannya dapat dipertahankan secara berkelanjutan. ${ }^{38}$ K.H. Moh. Irfan Sholeh, menyatakan bahwa pesantren harus menanamkan nilai-nilai

\footnotetext{
${ }^{36}$ Profil Pondok Pesantren Bahrul Ulum Tambakberas Jombang, 2011, hlm. 10-11.

${ }^{37}$ Wawancara dengan K.H. Moh. Hasib Wahab, Ketua Majelis Pengasuh PP Bahrul Ulum, Kamis, 14 Oktober 2018 bertempat di Kantor Yayasan PP Bahrul Ulum Tambakberas Jombang.

${ }^{38}$ Ibid.
} 


\section{Nilai-Nilai Pendidikan Karakter Di Pondok Pesantren}

Bahrul Ulum Tambakberas Jombang

luhur kepesantrenan itu kepada semua santrinya, karena jika tidak, maka hilanglah ruh pesantren..$^{39}$

Berikut ini uraian satu demi satu kesepuluh nilai-nilai pendidikan karakter yang dikembangkan PP Bahrul Ulum:

\section{Nilai Keimanan}

PP Bahrul Ulum sangat memperhatikan nilai-nilai keimanan untuk diajarkan kepada santrinya. Hal ini sebagaimana dinyatakan dalam tujuan pendidikannya, yaitu mencetak anak didik menjadi manusia beriman, bertakwa, beramal salih, dan berakhlak karimah.40

Nilai keimanan meliputi keyakinan kepada Allah swt. sebagai Sang Pencipta, para malaikat pesuruh Allah, Rasulullah Muhammad saw. sebagai utusan Allah, dengan membawa kitab al-Qur'ān yang merupakan wahyu Allah sebagai sumber ajaran yang benar, serta kehendak dan kuasa Allah terhadap semua ciptaan-Nya. Karena itu, yang pertama kali diajarkan kepada santri di pesantren adalah pengetahuan tentang aqidah dan akhlak. Hal ini dimaksudkan untuk membekali mereka dasar-dasar keimanan dan akhlak karimah sebelum mempelajari ilmu-ilmu lainnya.

Ajaran tauhid sangat diutamakan di pesantren, karena misi utama pesantren adalah membentuk manusia yang beriman. Keimanan harus ditanamkan sejak dini,

\footnotetext{
${ }^{39}$ Wawancara dengan K.H. Moh. Irfan Sholeh, Ketua Umum Yayasas PP Bahrul Ulum, Kamis, 28 Oktober 2018, di ruang tamu Kantor Yayasan PP Bahrul Ulum Tambakberas Jombang.

${ }^{40}$ Profil Pondok Pesantren Bahrul Ulum
} 


\section{Ali Muttaqin}

sebelum anak diberikan pelajaran-pelajaran yang lainnya. Agama Islam sendiri mengajarkan bahwa setiap anak yang baru lahir, seharusnya di perdengarkan suara $\overline{a z a n ~ d a n ~ i q a ̄ m a h ~ s e b e l u m ~ i a ~ m e n d e n g a r k a n ~ s u a r a-s u a r a ~ l a i n n y a . ~ I n i ~ a r t i n y a, ~ d a l a m ~}$ proses pendidikan yang perlu diajarkan lebih awal adalah pengetahuan tentang keimanan, baru kemudian ilmu-ilmu yang lain. ${ }^{41}$

Anak didik yang dibekali dengan keimanan atau ketauhidan yang kokoh, ia akan tumbuh menjadi pribadi-pribadi yang bisa mengendalikan diri dan meyakini asal muasal mereka, apa yang harus dilakukan selama hidup di dunia, dan kesadaran bahwa kelak merekapun akan diminta pertanggung jawaban di hadapan Allah swt. atas segala perbuatan yang telah mereka lakukan. Sehingga dari pancaran keimanan ini, muncul pribadi-pribadi yang jujur, rendah hati, terbuka, bertanggung jawab, amanah dan berakhlak mulia.

\section{Nilai Kejujuran}

Nilai kejujuran (sidq/amānah) adalah nilai dasar yang harus dimiliki setiap individu. Jujur adalah perilaku menjadikan dirinya sebagai orang yang dapat dipercaya dalam perkataan, tindakan, dan pekerjaan. Menurut K.H. Ach. Hasan, sangat penting menanamkan kejujuran di pesantren. Jujur adalah salah satu sifat Nabi Muhammad saw., beliau memiliki empat sifat (siddiq, amānah, tablig dan fatānah) yang menjadikan beliau sebagai manusia sempurna (insān kamil) menurut Allah Swt. Șiddiq artinya benar-benar jujur, amānah artinya dapat dipercaya atau bertanggung

\footnotetext{
${ }^{41}$ Wawancara dengan K.H.Moh.Hasib Wahab, Kamis, 14 Oktober 2018 .
} 


\section{Nilai-Nilai Pendidikan Karakter Di Pondok Pesantren}

Bahrul Ulum Tambakberas Jombang

jawab, fatānah artinya cerdas, bertanggung jawab dan profesional, sedangkan tablig artinya menyampaikan, tablig dapat dipahami sebagai sifat terbuka atau transparan. Sifat-sifat inilah yang perlu dikembangkan lebih intesif kepada peserta didik kalau mau membentuk karakter anak. ${ }^{42}$

Di PP Bahrul Ulum, sifat-sifat Nabi itu diejawantahkan pada diri santri melalui berbagai kegiatan kepesantrenan, agar kelak menjadi manusia yang dapat meneladani sifat-sifat Nabi saw. Membentuk pribadi-pribadi yang dapat meneladani sifat-sifat Nabi itu lebih sulit dari pada menjadikan orang-orang pintar. Orang dinilai bener (betul) karena bersikap jujur, dapat dipercaya dan amanah, sedangkan orang dinilai pinter (pintar) karena ilmunya. Pesantren pada umumnya lebih mendahulukan bagaimana membentuk anak-anak menjadi pribadi-pribadi yang bener, jujur dan amanah, baru kemudian pinter. Inilah salah satu hal yang membedakan pendidikan pesantren dari pendidikan lainnya. ${ }^{43}$

Sifat jujur senantiasa ditumbuhkan pada santri (anak didik). Nilai kejujuran sebagai nilai karakter adalah nilai yang digerakkan oleh keimanan kepada Allah Swt. di dalam hati, berdasar ilmu yang benar, menyangkut segala aktivitas serta berdampak pada segala aspek kehidupan. Imam Ibnu Qayyim berkata, Iman asasnya adalah kejujuran (kebenaran) dan nifaq asasnya adalah kedustaan. Tidak akan pernah bertemu antara kedustaan dan keimanan melainkan akan saling bertentangan

\footnotetext{
${ }^{42}$ Hasil wawancara dengan Drs. K.H.Ach. Hasan, M.Pd.I., Pengasuh Asrama As-Sa'idiyah 2 Pondok Bahrul Ulum, Sabtu, 2 Nopember 2018 di kediamannya.

${ }^{43}$ Ibid.
} 


\section{Ali Muttaqin}

satu sama lain. Allah mengkhabarkan bahwa tidak ada yang bermanfaat dan mampu menyelamatkan seorang hamba dari azab, kecuali kejujurannya (kebenarannya).44 Dalam sebuah hadis Nabi dari Abdullah bin Mas eud Rasulullah Saw bersabda, yang artinya:

Artinya: Dari Abdullah bin Mas"ud ra dari Nabi Saw. beliau bersabda: "Sesungguhnya kejujuran menunjukkan orang kepada kebaikan, dan kebaikan menunjukkan orang kepada surga. Seseorang berkata jujur sehingga dia menjadi orang yang jujur. Sesungouhnya kedustaan menunjukkan orang kepada dosa, dan dosa menunjukkan orang kepada neraka. Seseorang berkata dusta sehingga di sisi Allah dia ditulis sebagai pendusta". (Muttafaq 'alaih). ${ }^{45}$

\section{Nilai Keikhlasan}

Keikhlasan termasuk nilai yang dipegang kuat oleh PP Bahrul Ulum, dan ditanamkan kepada semua warga pesantren, baik santri, pengurus pondok maupun ustaz. Ikhlas adalah melakukan suatu perbuatan atau memberikan sesuatu dengan hati tulus dan tanpa pamrih. Orang ikhlas selalu dapat melakukan yang terbaik (doing the best) dan memberikan sesuatu yang terbaik (giving the best) tanpa peduli terhadap penilaian dan penghargaan yang diberikan orang lain. Di PP Bahrul Ulum, nilai keikhlasan itu tampak pada sikap hidup keseharian dengan dipeliharanya keyakinan hidup, bahwa segala aktivitas hidup harus berupaya memperoleh

\footnotetext{
${ }^{44}$ Ibnu Qoyim dalam Ahmad Mu'adz Haqqi, Al-Arba'un Hadisan fì al-Akhläq Ma'a Syarhihä (Malang: Darut At Thawiq Riyadh KSA, 1993), hlm. 202.

${ }^{45}$ Imam Nawawi, Riyạd al-Șalihìn (Jakarta: Pustaka Azzam, 2008), hlm. 62.
} 


\section{Nilai-Nilai Pendidikan Karakter Di Pondok Pesantren \\ Bahrul Ulum Tambakberas Jombang}

keridaan Allah swt., seperti semangat beribadah, belajar, mengajar dan mendidik untuk mendapatkan rida Allah swt.

Di pesantren, kiai mengajar dan mendidik santri semata-mata untuk beribadah kepada Allah swt., dan tanpa mengharapkan upah/imbalan dari kegiatan mengajarnya. Bagi kiai, mengajar adalah panggilan tugas untuk melaksanakan amanat mengamalkan ilmu pengetahuan, lebih-lebih pengetahuan agama dalam rangka ibadah. Sikap kiai itu didasarkan pada sabda Nabi "Balligú 'annì wa lau ayah" (ajarkan apa yang kamu peroleh dari Saya meskipun satu ayat). Para kiai berkeyakinan bahwa imbalan dari mengajar para santri itu akan diberikan oleh Allah dari jalan min haisu la yahtasib (pemberian/karunia Allah yang tidak diperhitungkan sebelumnya).

Demikian pula bagi santri agar menghindari adanya niat dan maksud untuk mendapatkan harta, kedudukan dan kekayaan dari kegiatan belajarnya. Semua kegiatan diniatkan sebagai ibadah untuk mengharapkan rida Allah swt. Menurut K.H. Ach. Hasan, bahwa meskipun santri belajar di sekolah atau madrasah dan jurusan yang berbeda-beda sesuai dengan minat dan bakat yang mereka miliki. Mereka memiliki cita-cita yang bermacam-macam, seperti ingin jadi kiai, pegawai atau pengusaha. Akan tetapi itu semua harus diniatkan untuk beribadah kepada Allah, dan bukan untuk mencari kesenangan dunia semata, maka disitulah terdapat keikhlasan dalam belajar. ${ }^{46}$

${ }^{46}$ Hasil wawancara dengan Drs. K.H. Ach. Hasan, M.Pd.I, Sabtu, 2 Nopember 2018. 


\section{Ali Muttaqin}

Nilai keikhlasan meliputi semua suasana kehidupan di pesantren. Kiai dan ustaz harus ikhlas dalam mengajar dan mendidik, santri harus ikhlas dalam belajar serta orang tua ikhlas dalam menyerahkan anak-anaknya kepada kiai untuk dididik di pesantren. Para kiai berpandangan bahwa keikhlasan merupakan kunci keberhasilan pendidikan. Karena itu, masalah keikhlasan di PP Bahrul Ulum sangat diutamakan, dengan dasar ikhlas ilmu yang diajarkan kepada santri akan bermanfaat sehingga menjadikan berkahnya ilmu itu.

\section{Nilai Ketaatan dan Penghormatan}

Di pesantren, santri harus taat kepada kiai, asal tidak dalam hal yang bertentangan dengan syariat Islam. Kiai di samping sebagai guru atau pendidik juga menduduki peran orang tua, ada baik atau buruknya santri menjadi tanggungjawab kiai. Taat adalah patuh dan setia terhadap ketentuan, peraturan atau norma tertentu. Ketaatan santri kepada kiai/ustaz dalam berbagai hal untuk mendapat rida atas ilmu yang telah diberikannya. Santri berkeyakinan bahwa berkahnya ilmu yang diperoleh di pesantren sangat terkait dengan rida kiai.

Perintah dan larangan kiai di PP Bahrul Ulum sudah tertuang dalam peraturan pondok, santri yang taat pada peraturan pondok berarti taat kepada kiai. Sejak lama telah berkembang keyakinan bahwa santri yang ingin ilmunya bermanfaat dan berkah, maka mereka harus taat kepada peraturan pondok. PP Bahrul Ulum memiliki seperangkat peraturan yang mengatur tata cara kehidupan santri di pesantren. Dalam hal kewajiban misalnya, semua santri berusia sekolah wajib bersekolah di 


\section{Nilai-Nilai Pendidikan Karakter Di Pondok Pesantren \\ Bahrul Ulum Tambakberas Jombang}

lingkungan pesantren, wajib mengaji, salat berjamah, sowan kepada kiai jika akan pulang atau datang dari rumah. Dalam hal larangan, santri dilarang mencuri, keluar malam, berpacaran, menggunakan narkoba dan merokok, mengormati orang yang lebih tua, serta tamu. Mereka wajib mentaati peraturan pondok untuk ketertiban dan kebaikan bersama. ${ }^{47}$

Perilaku santri PP Bahrul Ulum berlangsung dalam suasana yang khidmat dan mendalam. Tercipta suasana hidup yang harmonis antara kiai yang disegani, guru/ustaz yang membimbing dan dihormati, santri yang taat, penuh cinta serta hormat dengan segala keikhlasannya. Santri menyadari dan menghayati akan arti taat, hormat dan ikhlas. ${ }^{48}$ Lingkungan pesantren dengan suasana ketaatan dan penghormatan tentu dapat membentuk pribadi-pribadi santri yang taat dan patuh pada peraturan ketika mereka kembali ke masyarakat.

\section{Nilai Kesederhanaan}

PP Bahrul Ulum sangat menekankan nilai kesederhanaan kepada semua warga pesantren, terutama santri. Sikap ini termanifestasikan dari perilaku kiai dan santri yang selalu menampilkan kehidupan wajar dan proporsional dalam perkataan dan perbuatan. Tampak dari pola hidup keseharian di pesantren, semua santri tanpa terkecuali tinggal di asrama pondok, menempati kamar berukuran $3 \times 4$ meter yang dihuni rata-rata 12 orang santri. Dalam hal makan, santri tidak memasak sendiri,

\footnotetext{
${ }^{47}$ Hasil observasi terhadap PP Bahrul Ulum, Sabtu, 2 Nopember 2018

${ }^{48}$ Ibid.
} 


\section{Ali Muttaqin}

tetapi disediakan oleh pondok pesantren dengan menu yang sederhana tanpa dibeda-bedakan. Mereka tinggal membayar uang makan setiap bulan ke pondok.49 Hal ini disamping untuk membantu memenuhi kebutuhan santri, juga untuk melatih santri agar tidak terlalu konsumtif dan berlebihan dalam memenuhi kebutuhan makan. Dengan begitu, santri dapat menggunakan semua waktunya untuk belajar, baik sekolah maupun mengaji di pesantren.

Para kiai senantiasa menyarankan santri untuk tidak berlebihan, apalagi berfoya-foya. Meskipun mereka berasal dari keluarga berada (kaya), di rumah serba ada apa yang dimauinya, tetapi di pesantren dibatasi, mulai dari pakaian hingga makanan. Santri disarankan agar mau tirakat dengan memperbanyak puasa sunnat seperti puasa hari Senin dan Kamis, menyedikitkan makan, mengendalikan nafsu, tidak berlebihan dalam semua hal.

Pola hidup sederhana melatih santri memiliki kekuatan mental dan keteguhan jiwa agar kelak siap menghadapi berbagai macam keadaan, terutama keadaan yang tidak sesuai keinginan. Kesederhanaan juga dimaksudkan agar para santri mudah dalam mempelajari pengetahuan, ilmu yang dipelajarinya gampang meresap. Belajar hidup sederhana berarti siap menghadapi kenyataan hidup, pantang menyerah, tidak sombong dan mau bekerja keras. Sederhana artinya kesiapan untuk menghadapi berbagai tantangan dan rintangan hidup dengan tabah dan sabar.

\footnotetext{
${ }^{49}$ Hasil pengamatan terhadap aktivitas santri PP Bahrul Ulum Tambakberas Jombang, tanggal 21 - 28 Oktober 2018. 


\section{Nilai-Nilai Pendidikan Karakter Di Pondok Pesantren \\ Bahrul Ulum Tambakberas Jombang}

\section{Nilai Kemandirian}

Kemandirian adalah keadaan dapat berdiri sendiri tanpa bergantung pada orang lain. Di PP Bahrul Ulum, nilai kemandirian dikembangkan dalam semua aspek kehidupan pesantren, baik dalam hidup keseharian, pembelajaran maupun aspek institusional/kelembagaan. Dalam hidup keseharian santri memenuhi kebutuhannya sendiri dan tidak menggantungkan kepada orang lain. Misalnya santri mencuci pakaian, mengatur pakaian seragam sendiri, membersihkan kamar/asrama dan lingkungan pesantren, mengatur keuangan, mengatur kebutuhan belajar dan sebagainya. ${ }^{50}$

Dalam hal belajar santri mengatur waktu dan melakukannya sendiri, contohnya sehabis salat subuh berjamaah, mereka mengikuti pengajian kitab hingga pukul 06.00 WIB, selanjutnya bersekolah hingga pukul 13.00 WIB. Sepulang sekolah, mereka harus berada di pondok dan mengikuti kegiatan belajar di dalamnya hingga malam hari. ${ }^{51}$ Kebiasaan hidup mandiri membentuk santri memiliki kemandirian dalam hidup, berusaha memenuhi kebutuhan sendiri, memecahkan problem atau kesulitannya sendiri, dan tegar dalam menghadapi godaan dan tantangan hidup dalam masyarakat.

Dalam konteks kelembagaan pesantren, kemandirian ditunjukkan dengan tidak menggantungkan kepada pihak lain, pesantren sebagai lembaga pendidikan Islam tumbuh dan berkembang dengan mengandalkan kemampuan sendiri, tanpa tergoda

\footnotetext{
${ }^{50}$ Ibid.

${ }^{51}$ Ibid
} 


\section{Ali Muttaqin}

oleh kepentingan-kepentingan pragmatis yang bersifat sesaat. Sejarah perkembangan pesantren menunjukkan sikap kemandirian pesantren yang selalu menjaga jarak dengan penguasa, terutama ketika pesantren berada pada masa kolonial Belanda. Ketika masa penjajahan, pesantren mengambil posisi non kooperatif dengan penjajah Belanda, dan memilih lokasi di daerah pedalaman yang jauh dari pengaruh penjajah. Saat itu, pesantren berfungsi ganda, sebagai lembaga pendidikan dan lembaga perjuangan melawan penjajah Belanda.

\section{Nilai Persaudaraan}

Nilai persaudaraan berarti jiwa ukhuwah, persaudaraan, dan pertemanan. Persaudaraan adalah sikap memperlakukan orang lain seperti memperlakukan saudara sendiri. Dari pengamatan peneliti diketahui bahwa kehidupaan di PP Bahrul Ulum diliputi suasana persaudaraan yang akrab, saling menghormati satu sama lain, walaupun santri yang datang dan belajar berasal dari berbagai daerah. Segala suka dan duka dirasakan bersama dalam jalinan persaudaraan keagamaan.

Tidak ada lagi dinding yang memisahkan mereka, meskipun mereka itu berasal dari berbagai latarbelakang yang berbeda. Suatu contoh, santri yang berasal dari Pulau Jawa hidup bersama, bahkan sekamar dengan santri dari luar pulau Jawa, mereka hidup rukun, bersahabat, dan tidak saling membedakan. ${ }^{52}$ Pada prinsipnya perbedaan tidak dijadikan sebagai faktor perpecahan tetapi perbedaan sebagai keberkahan dari Sang Maha Pencipta Allah swt.

\footnotetext{
${ }^{52}$ Hasil pengamatan terhadap aktivitas santri Pondok Pesantren Bahrul Ulum Tambakberas Jombang, tanggal $21-28$ Oktober 2018
} 
Di dalam pesantren, nilai ukhuwah itu terwujud pada suasana persaudaraan dan keakraban didalam komunitas pesantren (kiai-ustaz-santri) dengan jalinan perasaan keagamaan. Dari perasaan bersaudara timbullah sikap saling menolong (atta'äwun) di antara sesama santri. Mereka saling membantu dalam memenuhi kebutuhan keseharian, misalnya santri menolong mengambilkan nasi temannya yang sakit, mengantarnya berobat ke dokter, meminjami uang kepada teman yang memerlukan. Jika terjadi ketegangan dalam pertemanan sesama santri karena suatu persoalan, maka santri yang lebih senior berusaha membantu memecahkan persoalan dan mendamaikan mereka, sehingga jarang terjadi ketegangan dalam hubungan pertemanan apalagi pertengkaran sesama santri.

\section{Nilai Cinta Ilmu Pengetahuan}

Cinta ilmu pengetahuan adalah salah satu nilai yang ditanamkan kepada santri PP Bahrul Ulum. Para kiai pengasuh menghendaki santrinya memiliki ilmu pengetahuan, baik ilmu pegetahuan agama maupun ilmu pengetahuan umum (sains dan teknologi). Ilmu agama, seperti Ilmu tauhid, tafsir, hadis, fiqih serta ilmu akhlak mengantarkan manusia dapat memahami agama Islam dengan benar, meyakini dan mengamalkannya dengan ikhlas, dan berakhlak mulia.

Sedangkan Ilmu pengetahuan umum adalah matematika, ilmu alam, ilmu sosial dan humaniora, serta seni. Manusia dengan akalnya diberikan kemampuan untuk menyerap sejumlah ilmu pengetahuan, walaupun hanya sedikit dibandingkan 


\section{Ali Muttaqin}

dengan kesempurnaan ilmu Allah, tetapi tetap harus berpegang kepada kebenaran untuk mencari rida Allah swt.

Di antara beberapa tujuan pendidikan PP Bahrul Ulum adalah “Membentuk manusia yang cerdas, terampil, mandiri, bertanggung jawab kepada diri sendiri, masyarakat, agama dan bangsa atas ilmu pengetahuan yang diperolehnya". ${ }^{53}$ Dengan tujuan pendidikan tersebut, PP Bahrul Ulum tidak mendikotomikan antara ilmu pengetahuan agama dan ilmu pengetahuan umum. Kedunya dipandang sama-sama penting bagi kehidupan manusia. Jika ilmu agama bersumber pada ayat-ayat qauliyah (firman Allah) yang mengatur tata cara berhubungan dengan Allah, sesama manusia maupun dengan lingkungan alam, maka ilmu pengetahuan umum bersumber pada ayat-ayat kauniyah (fenomena alam), yang karakternya berbasis kepada hukum alam sebab-akibat hasil ciptaan Allah Swt. yang sering disebut dengan sunatullah.

Untuk mengajarkan kedua bidang ilmu tersebut, PP Bahrul Ulum menyelenggarakan dua jalur pendidikan, yaitu jalur kepesantrenan untuk mengajarkan ilmu agama, dan jalur madrasah dan sekolah formal untuk mengajarakan ilmu pengetahuan umum. Juga menyelenggarakan kursus-kursus keterampilan seperti IT, bahasa asing dan jurnalistik untuk membekali keterampilan santri.

Para santri didorong untuk mencintai kedua bidang ilmu tersebut dan tidak membeda-bedakannya. Mereka menganggap penting terhadap keduanya dan

\footnotetext{
${ }^{53}$ Profil Pondok Pesantren Bahrul Ulum, 2011.
} 


\section{Nilai-Nilai Pendidikan Karakter Di Pondok Pesantren}

Bahrul Ulum Tambakberas Jombang

mempelajarinya dengan sungguh-sungguh tanpa meremehkan salah satunya. Dengan bekal kedua bidang ilmu tersebut, peserta didik dapat mengembangkan potensi dirinya untuk memiliki kekuatan spiritual keagamaan, kepribadian, akhlak karimah, kecerdasan, ilmu pengetahuan, serta keterampilan yang diperlukan dirinya, masyarakat, bangsa dan negara.

\section{Nilai Kebebasan}

Kebebasan adalah keleluasaan dan tidak adanya larangan atau kekangan dalam berpikir, bertindak sesuai dengan keinginan atau untuk memenuhi kebutuhan. Manusia adalah makhluk yang diberi ilmu oleh Allah swt. (Q.S. al-'Alaq [96]: 4-5), dan diberi kemampuan untuk mengembangkan ilmu dan daya nalarnya. Karena itulah manusia cenderung untuk bisa beraktualisasi diri serta berkreativitas. Tanpa kebebasan, manusia tidak dapat menemukan dirinya dan kreatif, dan manusia yang bebas akan menjadi terbuka dan berkembang. ${ }^{54}$ Nilai ini juga muncul didorong oleh kebebasan bertanggung jawab. Santri bebas berbuat sesuai minat dan mengembangkan bakatnya, yang berarti dia bebas berkreasi, tidak merasa dikekang dengan aturan, karena dia bebas dengan taatnya kepada aturan.

Kebebasan sebagai nilai pendidikan karakter di PP Bahrul Ulum adalah memberikan keleluasaan kepada santri untuk belajar dan berlatih sesuai dengan minat dan kemampuannya, bebas dalam berpikir dan berbuat, bebas dalam

\footnotetext{
${ }^{54}$ H.A.R. Tilaar, Perubahan Sosial dan Pendidikan, Pengantar Pedagogik Transformatif Untuk Indonesia (Jakarta: Gramedia, 2002), 174.
} 


\section{Ali Muttaqin}

menentukan masa depannya dan bebas dalam memilih jalan hidup di tengah-tengah masyarakat kelak, dengan berjiwa optimis dalam menghadapi kehidupan.

Di PP Bahrul Ulum, santri diberikan kebebasan untuk memilih jenis sekolah atau madrasah yang disediakan sesuai dengan minatnya. Demikian pula dalam hal pengajian di pesantren, mereka diberikan kebebasan untuk memilih bidang ilmu atau jenis kitab yang diajarkan oleh para kiai. Meskipun diberikan kebebasan, mereka tetap diarahkan agar memilih pengajian jenis pengetahuan atau kitab yang sesuai dengan tingkat kemampuan mereka.

Kebebasan yang dimaksud sebagai nilai pendidikan karakter adalah kebebasan yang bertanggung jawab dan dalam koridor ajaran Islam, seperti yang dinyatakan oleh K.H. Hasib Wahab, bahwa kebebasan dalam arti tidak dibatasinya santri dalam hal berpikir dan menentukan sesuatu. Namun demikian, kebebasan itu harus disertai dengan tanggungjawab dan dalam batas-batas syari'ah Islam, baik sebagai santri maupun hamba Allah. Sebagai santri harus tetap taat pada aturan pondok. Sebagai hamba Allah harus taat dan patuh pada syari'at Allah, berbuat yang terbaik untuk kemaslahatan hidup umat, menjaga kelestarian lingkungan dan berbuat untuk kemakmuran bersama. ${ }^{55}$

\section{Nilai Kepemimpinan}

PP Bahrul Ulum tidak hanya membekali peserta didik (santri) dengan ilmu pengetahuan, baik pengetahuan agama maupun umum (sains), tetapi juga dengan

\footnotetext{
${ }^{55}$ Hasil wawancara dengan Drs. K.H. Moh. Hasib Wahab, Kamis, 14 Oktober 2018.
} 


\section{Nilai-Nilai Pendidikan Karakter Di Pondok Pesantren \\ Bahrul Ulum Tambakberas Jombang}

kemampuan dibidang kepemimpinan (leadership). K.H. Moh. Hasib Wahab, menyatakan bahwa salah satu keterampilan yang diberikan kepada santri PP Bahrul Ulum, adalah keterampilan dibidang keorganisasian atau kepemimpinan. Keterampilan ini sangat penting untuk dimiliki para santri sebagai bekal ketika sudah tamat dari pesantren dan kembali ke daerah asalnya masing-masing. Santri adalah calon ulama atau kader-kader pemimpin masyarakat, maka sejak di pesantren perlu mempelajari ilmu kepemimpinan, berlatih memimpin dan menghayati jiwa pemimpin. ${ }^{56}$

Nilai kepemimpinan berkaitan dengan kemampuan dan kemauan seseorang untuk mempengaruhi atau memprakarsai orang lain agar berpikir dan bertindak sesuatu untuk mencapai suatu tujuan bersama. Kepemimpinan juga berarti kecakapan seseorang yang sanggup mendorong atau mengajak orang lain untuk melakukan sesuatu berdasarkan penerimaan kelompoknya, dan memiliki keahlian khusus yang tepat bagi situasi khusus.

Menurut Sondang P. Siagian, kepemimpinan adalah mendorong dan mengajak orang lain yang semula berpikir dan bertindak individualistik dan ego sentrik berubah menjadi perilaku kelompok atau organisasi. ${ }^{57}$ Jadi nilai kepemimpinan adalah butir nilai yang terwujud dalam kemampuan, kemauan dan kecakapan seseorang untuk mempengaruhi dan memprakarsai orang lain agar berpikir dan bertindak sesuatu.

${ }^{56}$ Ibid.

${ }^{57}$ Sondang P. Siagian, Kepemimpinan dan Perilaku Organisasi (Jakarta: Gunung Agung, 1985), hlm. 12. 


\section{Ali Muttaqin}

Kepemimpinan itu dibutuhkan oleh setiap kelompok, umat atau bangsa. Suatu masyarakat atau bangsa akan tertib, aman dan damai jika ada pemimpinnya yang mampu mengatur mereka. Syariat Islam membutuhkan pemimpin yang tegas yang mampu menegakkannya. Jadi hubungan kepemimpinan dengan agama itu ibarat dua sisi mata uang. Sisi pertama agama dan sisi kedua kepemimpinan. Karena itu, para santri perlu sekali dibekali kemampuan dibidang kepemimpinan. Nilai kepemimpinan dipandang sangat penting dan oleh karenanya perlu ditanamkan kepada para santri.

\section{F. Penutup/Kesimpulan}

Dari uraian hasil penelitian yang telah dipaparkan di atas dapat disimpulan bahwa nilai-nilai pendidikan karakter yang ditanamkan di PP Bahrul Ulum terdapat sepuluh butir, yaitu: keimanan, kejujuran, keikhlasan, ketaatan dan penghormatan, kesederhanaan, kemandirian, persaudaraan, cinta ilmu pengetahuan, kebebasan dan kepemimpinan. Nilai-nilai karakter tersebut berasal dari ajaran Islam yang bersumber pada al-Qur'ān, al-Hadits, dan kitab-kitab karya para ulama yang digali dari kedua sumber utama tersebut. Nilai-nilai karakter tersebut merupakan tolok ukur kebaikan seseorang yang harus diwujudkan dalam pikiran, sikap dan perilaku dalam hubungannya dengan Tuhan, diri sendiri, keluarga, masyarakat, bangsa dan lingkungan alam. 


\section{DAFTAR PUSTAKA}

Adisusilo, Sutarjo, J.R., Pembelajaran Nilai Karakter, Jakarta: PT. RadjaGrafindo Persada, 2012.

Agustian, Ary Gunanjar, Bangkit Dengan Tujuh Budi Utama, Jakarta: PT Arga Publishing, 2009).

Badr, Azimabadi, Etiquettes of Islamic Life, Kuala Lumpur: Adam Publisher Distributors, 2000).

Boang, Aisah dalam Supiana, Mozaik Pemikiran Islam: Bunga Serampai Pemikiran Pendidikan Indonesia, Jakarta: Ditjen Dikti, 2011.

Departemen Pendidikan Nasional, Kamus Besar Bahasa Indonesia

Echols, John M. dan Hassan Shadily, Kamus Inggris Indonesia, Jakarta: Gramedia, 1979).

Fathurrohman, Pupuh dkk., Pengembangan Pendidikan Karakter, Bandung: PT Refika Aditama, 2013.

Fitri, Agus Zainul, Reinventing Human Character: Pendidikan Karakter Berbasis Nilai $\mathcal{E}$ Etika di Sekolah, Yogyakarta: Ar-Ruzz Media, 2012.

Al-G̣alayaini, al-Syaikh Muștafa ,'Izah al-Nasyiinn, Bairut: Al-Maktabah al-'Asriyyah, t.t.

Al-Gazāìi, Imam, Ihya' Ulüm al-Dīn , Bairut: Dār al-Fikr, t.t.), III.

Al-Gazali, al-Imam Abi Hamid Muhammad bin Muhammad, Ayyuh al-Walad (Surabaya: Al-Hidayah, t.t.

http://nasional.kompas.com/20 Mei 2011. diakses tanggal 28 Pebruari 2016.

http://akhmadsudrajat.wordpress.com/2010/09/15/konsep-pendidikan-karakter, diakses tanggal 29 Pebruari 2016.

Ikhwan, Muzhoffar, Pendidikan Karakter: Konsep dan Implementasinya Dalam Pembelajaran di Sekolah/Madrasah, Makalah dipresentasikan dalam diskusi dosen Fakultas Agama Islam UII, tanggal 2 Nopember 2011. 


\section{Ali Muttaqin}

Kamisa, Kamus Lengkap Bahasa Indonesia, Surabaya: Kartika, 1997.

Kementerian Pendidikan Nasional, Naskah Akademik Pengembangan Pendidikan Budaya dan Karakter Bangsa, Tahun 2010.

Lickona, Thomas, Educating for Character: How Our Schools Can Teach Respect and Responsibility, New York: Bantam Books, 1991).

Majid, Abdul dan Dian Andayani, Pendidikan Karakter Perspektif Islam, Bandung: Remaja Rosdakarya, 2011.

Maksudin, Pendidikan Nilai Komprehensif Teori dan Praktik, Yogyakarta: UNY Press, 2009).

Mardiatmadja dalam Rohmat Mulyana, Mengartikulasikan Pendidikan Nilai , andung: Alfabeta, 2004.), hlm. 119.

Megawangi, Ratna, Membiarkan Berbeda Sudut Pandang Baru Tentang Relasi Gender, Bandung: Mizan, 1999.

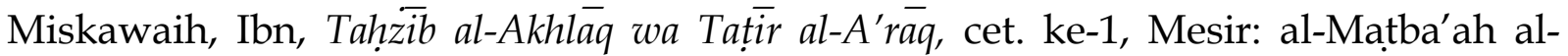
Mișriyyah, 1934.

Mulyana, Rohmat, Mengartikulasikan Pendidikan Nilai, Bandung: Alfabeta, 2004.

Mulyasa, E., Manajemen Pendidikan Darmaputera, Eka, Pancasila: Identitas dan Modernitas Tinjauan Etis dan Budaya, Jakarta: BPK Gunung Mulia, 1987.

Munir, Abdullah, Pendidikan Karakter, Yogyakarta: Pedagogia, 2010.

Nata, Abuddin, Akhlak Tasawuf dan Karakter Mulia, Jakarta: Radjagrafindo Persada, 2013.

Nawawi, Imam, Riyāẹ al-Ṣāihīin, Jakarta: Pustaka Azzam, 2008.Profil Pondok Pesantren Bahrul Ulum Tambakberas Jombang.

Qoyim, Ibnu dalam Ahmad Mueadz Haqqi, Al-Arba'ūn Hadisan fi al-Akhlāq Ma'ā Syarhiha, Malang: Darut At Thawiq Riyadh KSA, 1993.

Rutland, Mark, Karakter Itu Penting, terj. Ly Yen, Jakarta: Light Publishing, 2009.

Samani, Muchlas dan Harianto, Konsep dan Model Pendidikan Karakter Bandung: Remaja Rosdakarya, 2011. 


\section{Nilai-Nilai Pendidikan Karakter Di Pondok Pesantren}

Bahrul Ulum Tambakberas Jombang

Siagian, Sondang P., Kepemimpinan dan Perilaku Organisasi, Jakarta: Gunung Agung, 1985.

Sugiyono, Metode Penelitian Pendidikan: Pendekatan Kuantitatif, Kualitatif, dan $R \mathcal{E} D$, Bandung: Alfabeta, 2008.

Tilaar, H.A.R, Pendidikan Dalam Pembangunan Nasional Menyongsong Abad XXI, Jakarta: Balai Pustaka, 1990.

Zuchdi, Darmiyati, Humanisasi Pendidikan, Jakarta: Bumi Aksara, 2008. 
Ali Muttaqin

108 | Dinamika Vol. 3, No. 2, Desember 2018. 